WMJ (Warmadewa Medical Journal), Vol. 2 No. 2 November 2017, Hal. 44-51

\title{
Hemophilia A yang Didapat: Suatu Tinjauan tentang Diagnosis dan Manajemen
}

\author{
I Made Bakta \\ Divisi Hematologi dan Onkologi Medik \\ Bagian Penyakit Dalam Fakultas Kedokteran \\ Universitas Udayana/ RS Sanglah, Denpasar, Bali \\ E-mail: madebakta@yahoo.com
}

\begin{abstract}
Abstrak
Hemophilia A yang didapat atau acquired hemophilia $A$ (AHA) adalah penyakit perdarahan yang didapat (acquired), suatu penyakit yang jarang, penyakit autoimun yang ditandai oleh autoantibodi terhadap faktor VIII. Yang khas, penderita tidak menunjukkan riwayat perdarahan sebelumnya, datang dengan keluhan utama perdarahan spontan, terutama perdarahan kulit atau mukosa. AHA lebih banyak terjadi pada umur tua, baik pada laki maupun wanita dan dihubungkan dengan berbagai penyakit, seperti penyakit autoimun (lupus erithematosus sistemik, penyakit limfoproliferatif, artritis rematoid), keganasan atau kehamilan. Sekitar setengah dari penderita bersifat idiopatik. AHA didiagnosis jika dijumpai penderita tanpa riwayat perdarahan sebelumnya, baik personal atau keluarga, dimana pemanjangan aPTT (activated plasma thromboplastin time) tidak dapat dikoreksi setelah pencampuran dengan sejumlah volume yang sama dari plasma penderita dan plasma normal yang diinkubasi selama $2-4$ jam pada suhu $37^{\circ} \mathrm{C}$. Kadar FVIII:C menurun. Aktivitas titer inhibitor FVIII:C yang spesifik dapat dideteksi dan diukur dengan Bethesda assay atau dengan modifikasinya Nijmegen assay. Dalam pengelolaan AHA, pengendalian terhadap perdarahan merupakan prioritas pertama. Pada penderita dengan kadar inhibitor yang rendah, desmopressin dapat digunakan. Terapi FVIII bypassing agents (activated prothrombin complex concentrate atau recombinant FVIIa) diperlukan pada penderita dengan kadar inhibitor yang tinggi atau penderita dengan episode perdarahan yang berat. Secara bersamaan dilakukan eradikasi terhadap inhibitor (autoantibodi) untuk mengurangi risiko perdarahan berikutnya. Dianjurkan terapi lini pertama dengan kortikosteroid atau terapi kombinasi kortikosteroid dengan siklofosfamid. Untuk terapi lini kedua dapat dipakai rituximab, jika terapi lini pertama gagal atau terdapat kontraindikasi.
\end{abstract}

Kata kunci: hemophilia yang didapat, diagnosis, manajemen

\section{Abstract}

\section{[Acquired Hemophilia A: An Overview on Diagnosis and Management]}

Acquired hemophilia $A$ (AHA) is a rare acquired bleeding disorder, an autoimmune disease characterized by autoantibody directed against factor VIII. Typically, patients with no prior history of bleeding disorder, present with spontaneous bleeding, especially skin and mucosal bleeding. AHA occurs more frequently in the elderly, both in male and female and may be associated with several conditions, such as autoimmune diseases (systemic lupus erythematosus, lymphoproliferative disease, rheumatoid arthritis), malignancies and pregnancy. Around half of the patients are idiopathic. AHA is diagnosed in patients without previous personal or family bleeding history in which prolonged activated partial thromboplastin time is not corrected after mixing and incubating for $2-4$ hours at $37^{\circ} \mathrm{C}$ equal volumes of patient and normal plasma. FVIII:C levels are reduced and a specific FVIII inhibiting activity is detected and measured by the Bethesda assay or its Nijmegen modification. In the management of AHA, control of acute bleeding is the first priority. In patients with low level inhibitor, desmopressin may be used. But FVIII bypassing agents (activated prothrombin complex concentrate and recombinant activated FVII) are required for patients with high titre of antibody or with serious bleeding episode. Immediate autoantibody eradication to reduce subsequent bleeding risk should be performed. It is recommended initial treatment with corticosteroid or combination therapy with corticosteroid and cyclophosphamide and suggest second-line therapy with rituximab if first-line therapy is fails or is contraindicated.

Key words: acquired hemophilia A, diagnosis, management 


\section{PENDAHULUAN}

Hemophilia A yang didapat (Acquired hemophilia $A=$ AHA) adalah penyakit yang jarang dijumpai tetapi dapat menimbulkan perdarahan yang mengancam jiwa, akibat terbentuknya autoantibodi terhadap faktor VIII ${ }^{[1]}$ Autoantibodi adalah antibodi yang ditujukan terhadap antigen dari tubuh sendiri (auto-antigen) yang disebabkan oleh gangguan pada immune surveillance. Antibodi ini bersifat neutralizingantibody yang mengikat FVIII sehingga tidak efektif disertai clearance yang meningkat sehingga kadar FVIII menurun. Penurunan kadar FVIII menimbulkan gangguan koagulasi yang berakibat terjadinya perdarahan.

AHA berbeda dengan "classical hereditary hemophilia A" karena "classical hereditary hemophilia $A$ " merupakan penyakit herediter yang diturunkan secara resesif dan sex-linked, diderita sejak lahir dan sebagian besar mengenai laki-laki, sedangkan AHA adalah penyakit yang didapat, mulai setelah umur dewasa atau tua, mengenai baik laki-laki ataupun wanita. ${ }^{[2]}$

\section{EPIDEMIOLOGI}

AHA merupakan penyakit yang sangat jarang dengan insiden 0,2 - 1,0 kasus per satu juta penduduk. Insiden meningkat dengan meningkatnya umur, menjadi $0,045 / 1$ juta/tahun untuk umur $<16$ tahun dan 14,7 kasus/1 juta/tahun pada umur di atas 85 tahun. $^{[3]}$ Angka insiden yang dilaporkan mungkin lebih rendah dari yang sebenarnya karena diagnosis AHA sangat sulit sehingga banyak kasus yang terlewatkan. ${ }^{[1,4]}$ Umur rata-rata secara keseluruhan dari AHA adalah 73,9 $(61,4-$ $80,4)$ tahun. Distribusi umur AHA bersifat bifasik, puncak pertama yang lebih rendah pada kelompok umur 20 sampai 30 tahun, dengan puncak kedua yang lebih tinggi pada kelompok umur 68 sampai 80 tahun. Secara umum AHA mengenai kedua jenis kelamin, wanita lebih dominan pada kelompok muda sedangkan pada kelompok tua laki-laki lebih dominan. Rasio laki-laki berbanding wanita adalah 1:0,88. ${ }^{[1,2]}$ Angka kematian penderita AHA adalah 7,9-22\%. [1]

\section{PENYAKIT DASAR DAN PATOGEN- ESIS}

Sekitar 50\% kasus AHA bersifat idiopatik, sedangkan 50\% disertai penyakit dasar (underlying disease). Penyakit dasar yang dijumpai adalah penyakit autoimun, tumor solid, penyakit limfoproliferatif dan kehamilan. ${ }^{[5]}$ Penyakit autoimun termasuk lupus eritematosus sistemik, artritis rematoid dan sindroma Sjogren, merupakan $17-18 \%$ dari penyakit dasar. ${ }^{[5]}$ Sekitar $10 \%$ kasus AHA timbul pada periode pospartum, biasanya pada primipara dan timbul dalam waktu 3 bulan setelah persalinan. ${ }^{[1]}$ Penyakit dasar lain adalah tumor solid, keganasan limfoproliferatif, penyakit kulit (pemphigus dan epidermolysis bulosa). AHA juga dihubungkan dengan pemakaian obat, seperti penisilin dan interferon. ${ }^{[7]}$ Gambaran penyakit dasar AHA dapat dilihat pada Tabel 1 .

Tabel 1 Penyakit yang dihubungkan dengan $\mathrm{AHA}^{[1,2,7]}$

$\begin{array}{ll}\text { Idiopatik } & 50-51 \% \\ \text { Kehamilan } & 10 \% \\ \text { Penyakit autoimun } & 17-18 \% \\ \quad \text { - Lupus eritematosus sistemik } & \\ \quad \text { - Artritis rematoid } & \end{array}$


- Anemia hemolitik autoimun

Kolitis ulseratif

Kelainan kulit

$1,4 \%$

- Psoriasis

- Pemphigus

Obat

$3,4 \%$

- Penisilin

- Interferon

Keganasan

$11,8 \%$

- Tumor solid

- Keganasan limfoproliferatif

Antibodi yang terjadi pada AHA adalah suatu autoantibodi, berbeda dengan antibodi pada hemophilia herediter yang disertai inhibitor, antibodinya adalah aloantibodi. Aloantibodi bersifat poliklonal, sebagian besar terdiri dari IgG4. Sedangkan autoantibodi pada AHA terdiri dari IgG1, IgG2 atau IgA dan IGM, yang bersifat noncomplement fixing dan non-precipitating immunoglobulins. ${ }^{[6,7]} \quad$ Aloantibodi menginaktivasi FVIII secara komplit (type I kinetics), sedangkan autoantibodi menginaktivasi FVIII secara inkomplit (type II kinetics). ${ }^{[6]}$ Pada penelitian 501 kasus di Eropa didapatkan kadar rata-rata aktivitas FVIII adalah 2 (1-5) IU/dl, pada $17,8 \%$ kasus kurang dari $1 \mathrm{IU} / \mathrm{dl}$ dan $>5$ IU/dl pada $24,3 \%$ kasus. Sekitar $15 \%$ orang yang kelihatan sehat mempunyai antibodi terhadap FVIII titer rendah tanpa terdapat gejala (asimtomatik). Aloantibodi merupakan neutralizing antibody, yang menyebabkan inaktivasi FVIII sehingga FVIII tidak efektif dan cepat dikeluarkan dari tubuh. ${ }^{[1]}$ FVIII merupakan kofaktor FIX, bersama dengan $\mathrm{Ca}^{++}$dan posfolipid membentuk kompleks $X$-ase (tenase). Tenase sangat esensial untuk sistem koagulasi intrinsik pada pembekuan darah, oleh karena itu defisiensi FVIII menyebabkan turunnya pembentukan thrombin sehingga terjadi perdarahan. ${ }^{[7]}$

\section{TERAPI UNTUK MENGHILANGKAN ANTIBODI ATAU INHIBUTOR}

Gejala klinik AHA berupa perdarahan pada orang dewasa, baik laki maupun wanita, tanpa adanya riwayat keluarga. Jenis perdarahan pada AHA adalah perdarahan subkutan yang luas (dijumpai pada lebih dari $80 \%$ kasus) disertai perdarahan pada jaringan lunak lainnya dan perdarahan mukosa, seperti hematom pada otot, perdarahan urogenital (termasuk perdarahan postpartum), hematemesis, dan melena. Dapat terjadi compartment syndrome, seperti penekanan pada saluran nafas. Perdarahan fatal terjadi pada $9-22 \%$ kasus, sedangkan perdarahan ringan yang tidak memerlukan terapi terjadi pada $30 \%$ kasus. Berbeda dengan "classical hereditary hemophilia" dimana perdarahan yang khas adalah hemarthros atau perdarahan otot karena trauma dan perdarahan jaringan lunak lainnya, sedangkan pada AHA hemarthros jarang

dijumpai. $^{[4]}$ Derajat perdarahan pada hemophilia herediter berbanding lurus dengan kadar FVIII, sedangkan pada AHA derajat perdarahan tidak berbanding lurus dengan kadar FVIII atau kadar inhibitor. Perbedaan antara hemophilia herediter dengan AHA dapat dilihat pada Tabel 2. 
Tabel 2 Perbedaan hemophilia herediter dengan hemophilia yang didapat $(\mathrm{AHA})^{[4]}$

\begin{tabular}{|c|c|c|}
\hline & Hemofilia herediter & Hemophilia yang didapat (AHA) \\
\hline 1 & Herediter, sex-linked recessive & Acquired, autoimmune disease \\
\hline 2 & $\begin{array}{l}\text { Dijumpai pada laki-laki, wanita hanya sebagai } \\
\text { karier }\end{array}$ & Dijumpai pada laki maupun wanita \\
\hline 3 & $\begin{array}{l}\text { Pada } 30 \% \text { kasus dijumpai inhibitor yang } \\
\text { bersifat aloantibodi }\end{array}$ & Merupakan penyakit autoimun dengan autoantibodi \\
\hline 4 & $\begin{array}{l}\text { Mulai sejak lahir, manifes pada umur } 2 \text { tahun } \\
\text { ke atas }\end{array}$ & $\begin{array}{l}\text { Pada umur dewasa-tua dengan puncak umur pada } \\
\text { kelompok } 60-80 \text { tahun, dan puncak lebih rendah } \\
\text { pada umur 20-40 tahun }\end{array}$ \\
\hline$\overline{5}$ & Antibodi poliklonal dengan IgG4 paling sering & Antibodi dengan IgG1, IgG2, IgA dan IgM \\
\hline 6 & $\begin{array}{l}\text { Perdarahan yang khas adalah hemarthros, } \\
\text { perdarahan otot karena trauma atau perdarahan } \\
\text { jaringan lunak lainnya }\end{array}$ & $\begin{array}{l}\text { Perdarahan sebagian besar }(>80 \%) \text { adalah } \\
\text { perdarahan subkutan yang meluas dan perdarahan } \\
\text { mukosa. Hemarthros jarang dijumpai }\end{array}$ \\
\hline
\end{tabular}

\section{DIAGNOSIS}

Suatu panel internasional merekomendasikan diagnosis AHA sebagai berikut: diagnosis AHA dipertimbangkan jika terdapat perdarahan akut atau yang baru terjadi (acute or recent bleeding) disertai dengan pemanjangan aPTT (isolated prolonged aPTT) dengan waktu prothrombin normal, tanpa riwayat perdarahan sebelumnya atau riwayat keluarga. ${ }^{[7,8]}$

Untuk diagnosis AHA harus dilakukan anamnesis dan pemeriksaan fisik yang teliti untuk mengetahui riwayat dan jenis perdarahan serta mencari adanya penyakit dasar . ${ }^{[4,8]}$ Oleh karena umur penderita pada umumnya sudah lanjut, maka pemeriksaan untuk mencari penyakit penyerta (komorbid) menjadi penting yang akan mempengaruhi terapi. ${ }^{[1]}$

Pemanjangan aPTT tunggal (isolated) merupakan pertanda laboratorik yang khas pada AHA. Pemanjangan aPTT dapat disebabkan oleh karena defisiensi faktor koagulan (FVIII, FIX, FXI atau FXII), adanya inhibitor (terhadap FVIII atau FIX) atau adanya lupus anticoagulant dan terapi dengan heparin. ${ }^{[9]}$ Untuk membedakannya dilakukan mixing test. Mixing test adalah pencampuran plasma penderita dengan plasma normal yang dilakukan pada suhu $37^{\circ} \mathrm{C}$, aPTT diukur segera dan setelah 2 jam inkubasi. Pada penderita dengan defisiensi faktor pembeku, aPTT akan kembali normal setelah mixing test. Jika terdapat autoantibodi/inhibitor atau lupus anticoagulant maka aPTT tetap memanjang atau terjadi perbaikan kurang dari $50 \%$. ${ }^{[4,10,11]}$

Pengukuran FVIII:C esensial dalam diagnosis AHA. Kadar FVIII:C yang rendah tanpa penurunan faktor lain (isolated low FVIII:C) sugestif untuk diagnosis AHA. ${ }^{[8]}$ Pengukuran kadar inhibitor dilakukan dengan tehnik Bethesda atau Nijmegen. Pemeriksaan lupus anticoagulant dilakukan untuk membedakan penyebab pemanjangan $\operatorname{aPTT}^{[7,8]}$

Langkah-langkah diagnosis AHA dianjurkan oleh Collins et al., ${ }^{[9]}$ adalah seperti pada Gambar 1. 


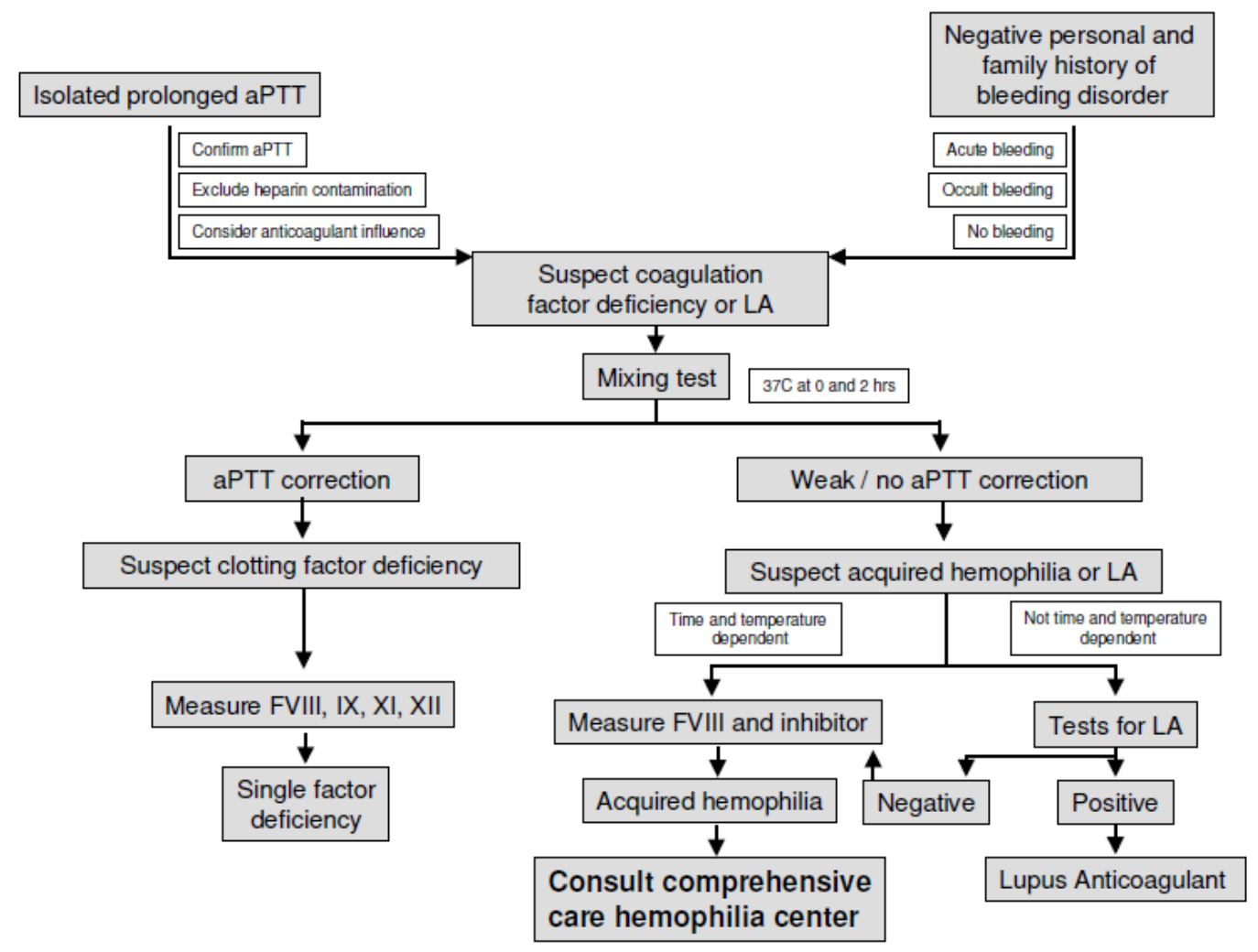

Gambar 1. Algoritma langkah-langkah diagnosis AHA. Dikutip dari: Collins P etal. $^{9}$. Consensus recommendation for the diagnosis and treatment of acquired hemophilia A. BMC Research Notes 2010, 3:161.

\section{MANAJEMEN}

AHA merupakan kasus yang jarang dijumpai sehingga sedikit dokter yang mempunyai keahlian dalam bidang ini, oleh karena itu penderita AHA sebaiknya dirujuk ke Pusat Perawatan Hemophilia. ${ }^{[6,9]}$ Pada dasarnya manajemen untuk AHA terdiri dari 2 jenis terapi yang diberikan secara simultan, yaitu: $:^{[12]}$

Terapi untuk perdarahan dan komplikasinya, dan

Terapi untuk mengeluarkan dan/atau eradikasi inhibitor (autoantibodi).

\section{Terapi untuk mengatasi perdarahan:}

Terapi untuk menghentikan perdarahan menjadi prioritas utama dalam terapi ${ }^{[8]}$ Terapi untuk mengatasi perdarahan ini tergantung dari derajat perdarahan, titer inhibitor dan penyakit dasar. Sebagian penderita mengalami perdarahan yang mengancam jiwa, tetapi sebagian mengalami perdarahan ringan. AHA pada postpartum atau karena obat, tidak memerlukan terapi, hanya melakukan pengawasan yang ketat, oleh karena inhibitor akan menghilang sendiri dalam beberapa bulan setelah persalinan atau obat dihentikan. ${ }^{[1]}$

Pada perdarahan minor atau kasus AHA tanpa perdarahan dengan titer antibodi yang rendah dan tidak memerlukan tindakan bedah, cukup dilakukan pengawasan yang ketat terhadap keadaan klinis dan laboratorik. Penderita harus dirawat di rumah sakit untuk melakukan pengawasan yang ketat. Inhibitor akan menghilang dalam beberapa bulan pada sekitar $25 \%$ kasus, terutama pada AHA dengan kehamilan atau akibat terapi antibiotika. ${ }^{[3]}$ Jika perdarahan memerlukan terapi, dimana kadar FVIII 
$>5 \%$ dan titer inihibitor rendah $(<2 \mathrm{BU})$, pemberian desmopressin (DDAPV) dapat meningkatkan FVIII. Desmopressin diberikan dengan dosis $0,3 \mu \mathrm{g} / \mathrm{kg}$ secara intravena. Pemberian desmopressin tidak boleh menunda pemberian bypassing agent jika perdarahan tidak terkontrol. ${ }^{[13]}$ International panel ${ }^{[8]}$ menganjurkan pemberian desmopressin jika bypassing agent tidak tersedia. Dapat juga diberikan faktor FVIII dengan dosis yang besar. Pemberian FVIII tidak pernah efektif pada penderita AHA dengan titer inhibitor yang tinggi. ${ }^{[3]}$

Pada perdarahan mayor, pilihan pertama adalah pemberian bypassing agent. Bypassing agent yang tersedia saat ini adalah rFVIIa (recombinant activated factor VII) dan activated prothrombin complex concentrate $(a P C C)$ dengan nama dagang FEIBA. Untuk rFVIIa (Novoseven) dosis yang diberikan adalah $90 \mu \mathrm{g} / \mathrm{kg}$ setiap 2-3 jam sampai perdarahan terkontrol, kemudian dosis diturunkan sampai perdarahan berhenti. ${ }^{[3,8,9]}$ FEIBA diberikan dengan dosis 50-100 IU/kg setiap 8-12 jam dengan dosis maksimum $200 \mathrm{IU} / \mathrm{kg}^{8,9}$ Komplikasi thromboemboli dilaporkan pada penggunaan bypassing agent, tetapi penggunaannya tetap dianjurkan jika bahaya perdarahan lebih mengancam jiwa. [8] Jika terapi dengan bypassing agent tidak dapat mengatasi perdarahan, ada yang menganjurkan immunoadsorption atau plasmapheresis untuk mengeluarkan inhibitor atau antibodi. ${ }^{[8]}$

European Acquired Haemophilia (EACH2) Registry, yang melaporkan 482 penderita dengan satu atau lebih episode perdarahan, 144 (30\%) tidak mendapat terapi untuk perdarahan; 31 orang hanya diobati secara simtomatik saja. Diantara 307 penderita yang diobati dengan first-line hemostatic agent, $174(56,7 \%)$ mendapat rFVIIa, APCC 63 (20,5\%), FVIII 56 $(18,2 \%)$ dan $14(4,6 \%)$ dengan DDAV (desmopressin). Perdarahan dapat dikontrol pada 269 dari 338 penderita $(79,6 \%)$ yang diobati dengan first-line hemostatic agent. Keberhasilan penghentian perdarahan adalah sama pada terapi rFVIIa dan APCC yaitu 93\%. ${ }^{[14]}$ Jika preparat rFVIIa tidak tersedia atau tidak terjangkau karena biaya, Yang et al ${ }^{[15]}$ memakai APCC dengan dosis kecil dengan hasil cukup baik, meskipun ini hanyalah pengalaman dari satu institusi saja.

\section{Terapi Untuk Menghilangkan Antibodi atau Inhibitor}

Eradikasi antibodi dengan imunosupresan harus diberikan segera setelah diagnosis AHA ditegakkan. Belum ada standar terapi yang tepat untuk eradikasi inhibitor. Dua regimen yang paling sering dipakai adalah: (1) kortikosteroid; (2) gabungan kortikosteroid siklofosfamid. Steroid yang diberikan adalah prednisolon $1 \mathrm{mg} / \mathrm{kg}$ atau kombinasi prednisolon dengan siklofosfamid 1-2 mg/ kg. Sekitar 70-80\% kasus akan mengalami remisi. Waktu rata-rata remisi adalah 5 minggu. Jika dalam 2-3 minggu FVIII tidak naik maka harus dicari terapi alternatif lain. ${ }^{[9]}$ Pada suatu penelitian dengan 249 kasus, mortalitas tanpa terapi adalah $41 \%$, dengan terapi imunosupresif mortalitas turun menjadi $20 \%{ }^{[8]}$ Penelitian dari European Acquired Hemophilia Registry mendapatkan bahwa imunosupresi dengan kortikosteroid dikombinasi dengan siklofosfamid memberi hasil remisi $70 \%$, lebih baik dibandingkan kortikosteroid sendiri yaitu sebesar $48 \%{ }^{[13]}$ Yang et al. ${ }^{[15]}$ mendapatkan terapi dengan kortikosteroid atau kombinasi kortikosteroid dengan siklofosfamid memberikan remisi komplit sebesar $89 \%$.

Terapi lini kedua untuk eradikasi inhibitor adalah pemakaian rituximab. Penelitian oleh European Acquired Hemophilia Registry mendapatkan bahwa rituximab-based regimens menghasilkan remisi $61 \%{ }^{[13]}$ Dosis rituximab adalah 375 $\mathrm{mg} / \mathrm{m} 2 /$ minggu diberikan setiap minggu selama 4 minggu. ${ }^{[7,16]}$ Sarah et al., ${ }^{[17]}$ memakai RCVP (rituximab, cyclophosphamid, vincristine dan prednison) atau RCV (rituximab, cyclophosphamide dan prednison) 
mendapatkan hasil yang cukup baik, meskipun ini adalah hanya hasil dari satu institusi.

\section{DAFTAR PUSTAKA}

1. Franchini M, Gandini G, Paolantonio T, Mariani G. Acquired Hemophilia A: a concise review. Am J Hematol 2005;80:55-63

2. Knoeble P, Marco P, Baudo F, Collins P, Huth-Kuhne A, Nemes L, Pellegrini F, Tengborn L, Levesque H. Demographic and clinical data in acquired hemophilia A: results from the European Haemophilia Registry $(\mathrm{EACH} 2)$. J Thromb Hemostasis 2012;10:622-31

3. Janbain M, Leissinger CA, KrusseJarres R. Acquired hemophilia A: emerging treatment options. J Blood Med 2015;6:143-50.

4. Collins PW, Hirsch S, Baglin TP, Dolan G, Hanley J, Makris M, Keeling DM, Liesner RI, Brown SA, Hay CRM. Acquired hemophilia A in the United Kingdom: a 2-year national surveillance study by the United Kingdom Haemophilia Registry Centre Doctors' Organisation. Blood 2007;109:187077.

5. Flisinski M, Windyaga J, Stefanska E, Huszcaza S, Donderski R, Manitius J. Acquired hemophilia: a case report. Pol Arch Med Wewn 2008; 118:228-33

6. $\mathrm{Ma} \mathrm{AD}$, Carrizosa D. Acquired Factor VIII Inhibitors: Pathophysiology and Treatment. Hematology 2006:432-6

7. Sakurai Y, Takeda T. Acquired Hemophilia A: A Frequently Overlooked Autoimmune Hemorrhagic Disorders. J Immunol Res 2014, Article ID 320674.

8. Huth-Kuhne A, Baudo F, Collins P, Ingerslev J, Kessler CM, Levesque H, Castellano MEM, Shima M, StLouis J. International recommendations on the diagnosis and treatment of patients with acquired hemophilia

Hematologica 2009;94:566-73.

9. Collins P, Baudo F, Huth-Kuhne A, Ingerslev J, Kessler CM, Castellano MEM. Consensus recommendations for the diagnosis and treatment of acquired hemophilia A. BMC Reseach Notes 2010;3:161-9.

10. Kessler CM, Knobl P. Acquired hemophilia: an overview for clinical practice. European J Haematol 2016; 96 Suppl; 81:36-41

11. Coppola A, Capua MD, Minno MNDD, Carbone AM. Acquired Hemophilia: An Overview on Diagnosis and Treatment. The Open Atherosclr \& Thromb J 2009;2:2932

12. Zdziarska J, Musial J. Acquired hemophilia A: an underdiagnosed, severe bleeding disorder. Pol Arch Med Wewn 2014;124:200- 6.

13. Collins P, Baudo F, Knoeble P, Levesque H, Nemes L, Pellegrini F, Marco P, Tengborn L, Huth-Kuhne A. Immunosupression for acquired hemophilia A: results from the European Acquired Haemophilia Registry (EACH2). Blood 2012;120:47-55.

14. Baudo F, Collins P, Huh-Kuhne A, Levesque H, Marco P, Nemes L, et al. Management of bleeding in acquired hemophiliaA: results from the European Acquired Haemophilia (EACH2) Registry. Blood 2012;120:39-46

15. Yang $Y$, Xue F, Shi $H$, Wang $H$, Zhang L, Ji M, et al. Acquired Hemophilia A: Retrospective Analysis of 49 Cases From a Single Chinese Hemophilia Center. Clin Appl Thromb/Hemostasis 2015;2:35 $-40$

16. Franchini M. Rituximab in the treatment of adult acquired hemophilia A: A systematic review. Criticals Rev in Oncol/Hematol 2007;63:47-52

17. Sarah L, Prantik D, Gary B. Systemic Therapy in Acquired 
WMJ (Warmadewa Medical Journal), Vol. 2 No. 2, November 2017, Hal. 51

Hemophilia - A Single Institute

Experience. Ulster Med J

2016;85:187- 92 